\title{
The Relationship between Corporate Culture and Value at Different Life Cycle Stages
}

\author{
Sung Ook Park ${ }^{1}$, Seung Uk Choi ${ }^{1, *}$, Seong Tae $\mathrm{Kim}^{1}$ and Hyung Jong $\mathrm{Na}^{2}$ \\ 1 School of Management, Kyung Hee University, Seoul 02447, Korea; sopark@khu.ac.kr (S.O.P.); \\ goodthink365@naver.com (S.T.K.) \\ 2 School of Global Business Administration, Semyung University, Jecheon 27136, Korea; \\ freshna77@semyung.ac.kr \\ * Correspondence: suchoi@khu.ac.kr
}

Citation: Park, S.O.; Choi, S.U.; Kim, S.T.; Na, H.J. The Relationship between Corporate Culture and Value at Different Life Cycle Stages. Sustainability 2021, 13, 2334. https:// doi.org/10.3390/su13042334

Academic Editor: Lucian-Ionel Cioca

Received: 19 January 2021

Accepted: 16 February 2021

Published: 21 February 2021

Publisher's Note: MDPI stays neutral with regard to jurisdictional claims in published maps and institutional affiliations.

Copyright: (c) 2021 by the authors. Licensee MDPI, Basel, Switzerland. This article is an open access article distributed under the terms and conditions of the Creative Commons Attribution (CC BY) license (https:// creativecommons.org/licenses/by/ $4.0 /)$.

\begin{abstract}
Despite the general agreement that a firm embodies its own culture, there is still a lack of empirical research on how a firm's culture affects its value. Another caveat on previous studies is that they implicitly assume that a firm's culture does not vary over time. In this paper, we examine the following two questions to address this lack: (1) Does a firm's culture affect the firm's value? (2) If a firm's culture varies at different life cycle stages, do these changes have an impact on firm value? By using a competing values framework, we identify four types of corporate culture-adhocracy, market, clan, and hierarchy-and use life cycle stages to proxy for changes in a firm's environment. The results reveal that adhocracy culture has a positive effect on a firm's value. In contrast, we find a negative association between hierarchy culture and a firm's value. This can be interpreted as the features of adhocracy culture, which gives autonomy to its members (flexible and discretion) and keeps challenging a firm to grow (external focus and differentiation), positively impacting firm value more than the other cultures. Furthermore, at a growth stage in which a firm faces dynamic environmental changes, both adhocracy and clan cultures have an incrementally positive effect on firm value. This implies that firms in mature or decline stages lose dynamic changes in their operational environment, therefore, the effect of culture on firm value is restricted in those stages.
\end{abstract}

Keywords: corporate culture; flexible culture; external-oriented culture; firm value; life cycle stages

\section{Introduction}

How should we define the corporate culture? There are various definitions of corporate culture in the existing literature, but the most common identifies it as the shared norms and beliefs of an organization [1]. Under this definition, corporate culture would have a pervasive impact on a firm. This is because a firm's culture not only identifies who its stakeholders are, but also suggests how a firm should form a relationship with them.

It has been suggested that a corporate culture should be considered a good culture if it promotes an organization's effectiveness [2]. Managers, of course, would thus consider good corporate culture a tacit resource that can positively influence their firms' values. The problem lies in the fact that making changes in order to improve corporate culture can be costly and can bear the risk of stirring up resistance from stakeholders. It is thus essential for both managers and academics to examine which types of corporate culture are appropriate for a firm's current status and objectives. Despite the findings from prior literature, there is still a lack of empirical research regarding how a firm's culture affects its value. To fill the void, in this paper, we propose two research questions that have not been examined in prior research: (1) Does a firm's culture affect the firm's value? (2) Does the relationship between corporate culture and value vary at different life cycle stages?

Regarding our first question, the related prior literature has focused on various subjects such as the relationship between corporate culture and short-term financial performance [3-6], innovation [7,8], leadership [9,10], strategies [11,12], job satisfaction $[13,14]$, 
and knowledge management $[15,16]$. There are few studies, however, regarding the relationship between corporate culture and the overall firm value. We thus examine the relationship using the Tobin's $Q$, which is widely used as a proxy for firm value.

As for our second question, there is a lack of empirical research on the corporate culture and value depending on firms' environmental changes. Theoretically, external environmental factors are assumed to be the determinants of corporate culture [17-19]. For example, the environmental changes that take place within other firms are often adapted by changing the internal structure of a firm, and firms with a culture that is more adaptive to external factors and with smaller information gaps between its members will perform more effectively than those without such characteristics. However, in general, the theoretical literature proposes that firms generally go through similar stages of development, a predictable pattern that can be characterized as life cycle stages. In our study, we aim to shed light on environmental changes with the application of the life cycle theory. Prior research uses the life cycle stage as a proxy of a firm's environment. For instance, Ref. [20] shows that firms at different life cycle stages have differential behaviors revealed by their cash flow patterns. Studies also show that a firm's environment changes with respect to its information uncertainty, and volatility in future returns and profits vary depending on life cycle stages (e.g., Ref. [21]). We thus examine whether the effects of corporate culture vary according to the change in life cycle stages.

The related literature uses life cycle stages to proxy environmental changes. In particular, Ref. [18] proposes that firms generally go through similar stages of development, a predictable pattern that can be characterized as life cycle stages. More related to our research, Refs. $[19,22]$ suggest a theoretical framework that supports the existence of an optimal culture that achieves corporate goals for firms in a certain stage. In our study, we aim to empirically shed light on the prior literature by applying environmental changes to the corporate culture with the application of life cycle theory.

To proxy cultures, we apply the competing value framework (hereafter, CVF) developed by Refs. [23,24], which has been widely used in related studies. According to CVF, a corporate culture is classified as one of four types: adhocracy, market, clan, and hierarchy. Next, following prior research, we divide a firm's life cycle into stages of growth, maturity, and decline [25-27], and examine each stage's impact on the relationship between culture and firm value.

Our findings are as follows. First, we find that adhocracy culture has a positive impact on firm value. In contrast, hierarchy culture has a negative impact on firm value, while the other two cultures (market and clan) have no significant impact on it. These can be interpreted as features of adhocracy culture, which gives autonomy to its members (flexible and discretion) and keeps challenging the firm to grow (external focus and differentiation), positively impacting firm value more than the other cultures. Second, we find that the effect of corporate culture on firm value varies at different life cycle stages. For instance, adhocracy and clan cultures have a positive incremental effect on firm value when the firm is in its growth stage. In contrast, other cultural types do not show any incremental effects throughout the life cycle stages. This implies that firms in mature or decline stages lose dynamic changes in their operational environment, and thereby the effect of culture on firm value is restricted in those stages.

Our study contributes to the literature in the following ways. First, to the best of our knowledge, this is the first study that finds a systematic relationship between corporate culture and firm value with a focus on life cycle stages. Second, we document that not culture itself, but a joint effect of culture and growth stage, enhances firm value. As a firm goes into its maturity stage, it engages in very few efforts in diversification or acquisition, and fails to make incremental innovative changes to products or services. The nature of this life cycle has the potential to offset innovation from corporate culture. These explanations offer some possible research topics to be tested in future research. Lastly, this study uses data from a national research institute to classify corporate culture, thus 
examining a relatively large number of samples compared to other empirical studies in this research area.

Our study has the following caveats. First, we find that the hierarchy culture has a negative impact on firm value. However, it has not been presented in such a way as to mitigate the negative influence of this culture. Even in the same culture, the impact may vary from company to company, so it is important to future research to identify and investigate those cross-sectional attributes of firms. Second, CVF may not completely match to the questionnaire we used. Although the CVF has been widely used in related studies, we admit that the framework may not be adequately applied to our study. Third, since it is the result of using Korean data, there may be a problem in generalizing it to other countries and companies. Lastly, we use the life cycle stage as a proxy for the environmental change of a firm. However, there may also be other alternatives. We believe our limitations to be addressed in the follow-up research.

\section{Theoretical Background}

\subsection{Studies on the Definitions and Types of Corporate Culture}

The literature offers a variety of definitions of corporate culture. For instance, culture can be defined as the common values, beliefs, inherent assumptions, and process routines of an organization or enterprise [1]. In other words, a firm's culture can be defined by its shared beliefs and behavioral norms, and basic assumptions. To be specific, the following are well-known definitions of corporate culture in academia. Ref. [28] emphasizes that cultures "provide group members with a way of giving meaning to their daily lives, setting guidelines and rules, reducing and containing the anxiety of dealing with an unpredictable and uncertain environment". Ref. [29] defines culture as "a set of norms and values that are widely shared and strongly held throughout the organization". Ref. [7] shows that cultural dimensions are shaped by employees' behaviors based on values, norms, and artifacts. The study finds that the organizational culture established by those factors fosters innovative behavior. In addition, the literature argues that being internally or externally oriented [30], or the ability to provide a clear vision and direction [31], affect the classification of cultural types. In our study, by following prior research, we also define culture as the set of shared norms and beliefs in an organization.

\subsection{Studies on Corporate Culture and Value}

Corporate culture influences the behavior of individuals in a firm, thereby affecting firm performance. The widespread agreement on good culture that enhances firm value requires firms to retain consistency in their behaviors. Ref. [32] suggests three benefits that may result from a positive corporate culture. The first is the enhanced coordination and control of the firm. If there is a widespread endorsement of the organizational values in the firm, as can be seen in a general agreement that certain kinds of actions or behaviors are acceptable while others are not, cases of unacceptable actions such as fraud can be detected and corrected more easily by employees rather than members of a formal hierarchy monitoring system. As self-supervision is usually more effective and less costly than a formal controlling structure [29], corporate culture may positively affect firm performance and value. Ref. [33], for example, shows how an error management culture facilitates communication about errors. The second benefit of a positive corporate culture is improved goal alignment between the firm and its members. As goal alignment not only provides a common direction for the firm but also helps members react properly in unexpected situations, it can contribute to a synergistic effect that is greater than the aggregation of the individual abilities of its members, while reducing political costs by mitigating conflicts of opinions regarding the firm's interests. Both of these benefits have a direct impact on the firm's performance, positively impacting firm value. Third, a positive corporate culture can also result in increased employee effort. Corporate culture binds employees more closely together with their firm by enhancing their commitment to the organization. It may, for 
example, lead personnel to see innovation as one of the organization's fundamental values, which may allow them to feel more involved in the innovative process [34].

\subsection{Studies on the Features of Cultures at Different Stages of the Life Cycle}

Recent studies document several features of the culture via different life cycles. First, Ref. [17] shows that firms transition from a clan culture to hierarchical culture through life cycle stages. In particular, the study documents that the majority of firms that belong to the introduction stage have a clan culture. In the growth and mature stage, still a large portion of firms are classified as having a clan culture. In contrast, in the decline stage, all the sample firms are classified as having a hierarchical culture. Ref. [35] divides cultural types into individualism, masculinity, uncertainty avoidance, and power distance, and examines the association between a culture and a firm's growth through overcoming financial constraints. The study finds evidence that among the four different cultures, individualism is related to a firm's growth stage. To summarize, the empirical studies show that firms may choose their optimal cultures depending on life cycle stages.

There are theoretical studies supporting this view. In particular, Ref. [19] shows that firms establish an optimal culture to achieve competitive advantages to facilitate innovation. Moreover, they describe that firm growth and industry evolution along with a firm culture guide the development of a firm in different business environments. Ref. [22] analyzes the optimal incentive scheme and corporate culture investment under given profit opportunities and market competition. The study then develops how the product and labor market size affect the equilibrium choices of culture. Specifically, they show that a firm in a competitive market with increasing market size, which can be interpreted as a growth stage, invests more in culture to establish a corporate identity.

Few studies have directly examined the relationship between a firm's life cycle and culture, but this relationship can be predicted through studies using various environmental factors related to life cycle stages. For instance, Ref. [36] shows that a long-term-oriented culture is related with higher IPO underpricing, while a culture with a higher degree of uncertainty avoidance reduces underpricing. As firms in the growth stage usually undertake IPO, this evidence suggests that certain types of culture at this stage support firms in raising external investment. Next, firms in the final stage of their life cycle either sell their businesses or seek changes through mergers and acquisitions. Whether firms with different cultures will have synergy after the merger would be an important research question. In this regard, Ref. [37] reports that the cultural differences positively affect post-acquisition performance.

Some other studies assume the opposite direction, that is, the effect of a firm's culture on environmental changes. For instance, using CVF, Ref. [38] finds that the clan, market, and especially adhocracy cultures have positive influences on organizational agility. The study interprets its result as a firm with flexible culture efficiently adjusts and responds to the rapid changes in the environment. Ref. [39] shows that a firm with a culture of high integrity will have lower investment cash flow sensitivity. As firms in the growth stage generally suffer from low accessibility to external finance, this finding implies that a highly integrated culture would help these firms to increase investment efficiency. Recent empirical studies have also investigated the life cycle stage of a firm in a specific culture that emphasizes social contribution activities. For instance, Ref. [40] shows a positive association between a humanistic culture and corporate social responsibility (CSR) activities.

To summarize, few studies have so far directly linked corporate culture to the life cycle stage, suggesting the need to investigate this area further. Furthermore, studies generally assume that the life cycle stages are sequential in nature, representing a hierarchical progression that is not easily reversible. Our study mitigates this by exploring the possibility that the impact of corporate culture would vary with changes in the life cycle stages. 


\section{Hypotheses Development}

Studies provide specific dimensions when defining corporate culture. For instance, Refs. $[23,24]$ have created what they have named as CVF. This framework has been widely used in academic research. The CVF defines four types of culture-adhocracy, market, clan, and hierarchy. These four types are defined by the two categories of flexibility or stability, and internal or external focus.

Based on this, when developing hypotheses, we use the CVF to divide a firm's culture into four dimensions. Quadrant 1, which represents adhocracy culture, is shaped by a higher flexibility and an external focus. It emphasizes the value of entrepreneurship, creativity, and adaptability. It stresses pioneering new markets, developing new products, being a leader, and engaging in innovative activities despite high risks.

Quadrant 2, which represents clan culture, is shaped by flexibility and an internal focus. It emphasizes participation and teamwork, as done by family-type organizations. Employee morale and self-actualization are higher in this culture. In contrast to externally oriented cultures, clan culture tends to prefer individual satisfaction over organizational performance. Due to the devotion and loyalty of its employees, this type of culture is expected to be positively related to financial performance compared to externally oriented cultures $[5,30]$.

Quadrant 3, which represents hierarchy culture, has the lowest discretion and focuses on internal stability. It stresses rules, regulations, and order. This kind of culture often shows severe resistance to change and innovation. Its bureaucratic nature is an obstacle when responding to environmental changes, but has advantages such as allowing for well-constructed internal processes that lead to the smooth functioning of the organization.

Quadrant 4, which represents market culture, emphasizes achievement and competitiveness by providing clarity of purpose and direction. It motivates employees by setting difficult but attainable goals and provides feedback on their performance [31]. It is regarded as a result-oriented workplace with an emphasis on winning, outpacing the competition, escalating share price, and being a leader in the market [4].

Corporate culture was found to be an essential resource for a company's outcomes [3]. Culture also can be seen as an integral part of the adaption process of an organization facing environmental change. This trait may be a useful predictor for firm performance and operational effectiveness [41]. Our research focuses on which type of corporate culture can be an indicator of higher firm value. Associations between cultural types and firm values are listed below.

\subsection{Adhocracy (Higher Flexibility and External Focusing) Culture and Firm Value}

Most prior studies have consistently reported the positive effects of an adhocracy culture on firm performance. Ref. [31] provides evidence that an adaptive orientation improves firm performance. Ref. [14] also indicates a relationship between innovative culture and job satisfaction. Collectively, firms that practice an adhocracy culture are expected to have higher financial and non-financial performance, ultimately leading to improved firm value. Nevertheless, previous studies still lack empirical evidence as they are based on experimental and survey-based firm performance data.

\subsection{Market (Lower Flexibility and External Focusing) Culture and Firm Value}

Prior studies show contradictory results regarding the effect of market culture on firm performance. For example, Ref. [7] and Ref. [30] empirically show that market orientation and innovation are positively associated with firm performance. By contrast, Ref. [42] provides indirect evidence for the negative effect of market culture, showing that it leads to lower job satisfaction. Thus, while market culture includes features that can enhance firm value, these features can be offset by other features that can weaken the relationship between this cultural type and sustainable financial performance. 


\subsection{Clan (Higher Flexibility and Internal Focusing) Culture and Firm Value}

Studies on the effect of clan culture on the firm also show mixed results. Using Japanese companies, Ref. [10] finds that clan culture is correlated with poor performance. Ref. [31] shows that a humanistic orientation similar to clan culture is indirectly related to firm performance, affecting firm performance indirectly through achievement orientation. In contrast, Ref. [8] reports the effect of group culture (the same as clan culture) on process innovation. Ref. [6] proves a positive relationship between involvement culture (also the same as clan culture) and market-based performance and market-to-book ratio. Other research also provides evidence regarding the positive effect of clan culture on firm value. Overall, clan culture is shown to be related to firm performance, but with an impact that is less significant than that of adhocracy culture [15].

\subsection{Hierarchy (Lower Flexibility and Internal Focusing) Culture and Firm Value}

Extensive studies have generally indicated that hierarchy culture has a negative effect on firm performance. Ref. [5] and Ref. [30] argue that the characteristics of hierarchy culture have negative implications for financial as well as other types of performance. In addition, research shows that organizational support, innovation, and goal orientation are related to higher performance, but that bureaucratic orientation, a key feature of hierarchy culture, is not.

Based on the discussion above, we predict that corporate culture types known for higher flexibility and an external focus are more positively related to firm value compared to culture types known for lower flexibility and an internal focus. Thus, we form our hypotheses as follows.

Hypothesis 1 (H1). Corporate cultural types with higher flexibility, discretion, and an external focus are positively related to firm value.

Hypothesis 1a (H1a). Adhocracy culture is more likely to be positively related to firm value than the other types of cultures.

Hypothesis $\mathbf{1 b}(\mathbf{H 1 b})$. Market and clan cultures are not related to firm value.

Hypothesis 1c (H1c). Hierarchy culture is more likely to be negatively related to firm value compared to the other types of cultures.

\subsection{The Incremental Effects of Life Cycle Stages on the Relation between Culture and Firm Value}

As explained above, since a good culture is believed to improve performance and since the stages of organizational development are related to performance, it is expected that culture is also related to the organizational life cycle. Considering that a life cycle is a set of phenomena common to all companies from their birth to their decline, environmental uncertainty may also be characteristic of certain life cycle stages.

Table 1 shows part of a contingency model of organizational development presented by Ref. [43]. The table shows that (objective) environmental uncertainty is highest at the initial stage (called the inception and early growth stages) in the whole life cycle, but relatively low at the maturity and decline stages. Prior research generally suggests that uncertainty is perceptual, rather than an objective interpretation of the environment $[19,22]$. We thus consider perceived environmental uncertainty as well. Perceived environmental uncertainty at the initial stage is also higher than it is in the maturity and decline stages. Organizational slack that can buffer environmental change also decreases as the life cycle progresses from the growth to the decline stage, as the firm becomes formal and bureaucratic. In other words, the effect of corporate culture on firm value is influenced more by life cycle when a firm is in its early growth stage than any in other stage, as the growth stage faces more environmental uncertainty, whether it be objective or perceived, but has the organizational slack to buffer these environmental changes. 
Table 1. A contingency model developed by Gupta and Chin (1994) [43].

\begin{tabular}{cccc}
\hline & Inception and Early Growth & Late Growth and Maturity & Decline \\
\hline $\begin{array}{c}\text { (Objective interpreted) } \\
\text { environmental uncertainty }\end{array}$ & high & usually high & usually high \\
\hline $\begin{array}{c}\text { (Perceived) environmental uncertainty } \\
\text { environmental change }\end{array}$ & relatively high & relatively low & relatively high \\
\hline $\begin{array}{c}\text { Organizational slack to buffer } \\
\text { enviring }\end{array}$ & medium and high & relatively decreasing & low \\
\hline
\end{tabular}

Ref. [32] insists that organizations with a strong culture may have greater difficulty responding to environmental volatility than those with a weak culture, as they may have more difficulty detecting environmental shifts and may be unwilling to accept the possible failures and uncertain returns that accompany the fundamental changes in organizational processes. This argument implies that strong cultures have very rigid characteristics. More flexible cultures, on the other hand, allow firms to better recognize environmental changes and adapt their routines in response to these changes.

Taking the above considerations into account, we expect that culture types with higher flexibility are more likely to be affected by life cycle stages, especially the early growth stage. Moreover, we predict that less flexible culture types are not affected by life cycle stages. Firms in the early stage of their life cycle require a different corporate culture to support their entrepreneurial activities, and to be successful in the growth stage, firms need to be able to respond appropriately to environmental changes by adopting alternative routines [32]. As these organizational characteristics are characteristics of adhocracy and clan cultures, we expect that these cultures will have an incremental effect on firm value in the earlier life cycle stage [35]. Collectively, we have formulated our second hypothesis as follows.

Hypothesis 2 (H2). The effect of corporate culture on firm value varies at different life cycle stages.

Hypothesis 2a (H2a). Firms with culture types with more flexibility (such as adhocracy and clan cultures) are affected by their life cycle stage, specifically the early growth stage.

Hypothesis $\mathbf{2 b}$ (H2b). Culture types with less flexibility (such as market and hierarchy cultures) are not affected by their life cycle stages.

\section{Research Design}

\subsection{Proxy of Corporate Culture}

To examine the effect of corporate culture on firm value, we use data from the Human Capital Corporate Panel (HCCP), which is published by the Korea Research Institute for Vocational Education and Training (KRIVET), a national research institute founded by the Korean government. Data from the HCCP have been widely used in recent studies examining the corporate cultures of Korean companies [44-46]. In general, the corporate culture proxies used in the previous studies are estimated from a survey that is selfdesigned and circulated by the researcher. In this study, however, since the Korean data we use are provided by the national labor research institute, they are not only constructed from a large number of observations, but are also relatively free from sample selection bias compared to those in previous studies. Therefore, we analyze these Korean companies which are subject to the HCCP survey.

The HCCP data are compiled by collecting survey data from the managers of the human resources departments of 500 companies. This survey has been conducted every two years since 2005 . Thus, the data are disclosed only for odd-numbered years. In our study, we use data from the last three surveyed years (2011, 2013, and 2015). We chose 12 questions from the questionnaire that we found were related to our definitions of corporate culture. These questions are listed in the Appendix A. Each item used a five-item 
Likert scale (1: Strongly Disagree, 2: Disagree, 3: Neither Agree nor Disagree, 4: Agree, 5: Strongly Agree). Respondents were asked to give a score from 1 to 5 representing how well the characteristics described their company. We conducted a factor analysis to categorize 12 questions into several groups.

The factor analysis we conducted with the scores given in response to the question items was performed in order to apply the CVF's culture classification. We also grouped the questions using the Varimax method, which rotates the factor axis at a right angle, to give the factors better convergency. This kind of approach has been broadly adopted in recent big data-driven analyses [47]. Thus, the groups are classified by the four factors as shown in Table 2. These classifications follow the four types of culture from CVF.

Table 2. Classification of questions by 4 factors.

\begin{tabular}{|c|c|c|c|c|c|c|}
\hline \multirow{2}{*}{ Variables } & \multicolumn{4}{|c|}{ Rotated Factor Pattern } & \multirow{2}{*}{ Cronbach $\alpha$} & \multirow{2}{*}{ Culture Classification } \\
\hline & Factor1 & Factor2 & Factor3 & Factor4 & & \\
\hline Q3 & 0.814 & 0.186 & 0.213 & 0.068 & \multirow{3}{*}{0.832} & \multirow{3}{*}{ Adhocracy } \\
\hline Q2 & 0.779 & 0.215 & 0.349 & 0.008 & & \\
\hline Q1 & 0.750 & 0.267 & 0.297 & -0.006 & & \\
\hline Q10 & 0.157 & 0.783 & 0.018 & 0.296 & \multirow{3}{*}{0.763} & \multirow{3}{*}{ Market } \\
\hline Q12 & 0.325 & 0.714 & 0.314 & 0.035 & & \\
\hline Q11 & 0.280 & 0.672 & 0.405 & 0.053 & & \\
\hline Q5 & 0.287 & 0.157 & 0.830 & 0.099 & \multirow{3}{*}{0.871} & \multirow{3}{*}{ Clan } \\
\hline Q6 & 0.270 & 0.234 & 0.808 & 0.078 & & \\
\hline Q4 & 0.346 & 0.054 & 0.772 & 0.015 & & \\
\hline Q7 & 0.111 & 0.394 & 0.612 & 0.232 & Excluded & Excluded \\
\hline Q9 & 0.008 & 0.175 & 0.002 & 0.845 & \multirow{2}{*}{0.645} & \multirow{2}{*}{ Hierarchy } \\
\hline Q8 & 0.031 & 0.080 & 0.192 & 0.829 & & \\
\hline
\end{tabular}

Factor analysis clusters each question based on its similarity with other questions. Here, Q1, Q2, and Q3 are categorized under Factor 1. Q10, Q11, and Q12 are categorized by Factor 2. Q4, Q5, Q6, and Q7 are categorized by Factor 3. As Q7 has a relatively low factor loading value (0.612), and as Cronbach $\alpha$ increases without Q7, we delete Q7 from our tests. Finally, Q8 and Q9 are categorized by Factor 4 .

To classify the types of corporate culture, we use the CVF model proposed by Ref. [34]. Factor 1 includes the characteristics of innovation, the possibility of new initiatives, and rewards for creativity, which are similar to the characteristics of adhocracy culture as described in the CVF. Factor 2 includes the characteristics of professionalism and the ability of employees to perform tasks, which are the characteristics of market culture as described in the CVF. Factor 3 includes the characteristics of intimacy among the members and teamwork, which are characteristics of clan culture. Finally, Factor 4 includes the direction of information flow or communication and the hierarchical atmosphere of the organization, which are related to hierarchy culture. Considering what these factors all indicate, we classify Factors 1-4 as four types of culture-adhocracy, market, clan and hierarchy culture, respectively.

Next, to quantify the types of corporate culture by firm-year for our empirical analysis, we calculate the average scores (FS1-FS4) given by the companies' human resource department managers (the respondents). If the average score is in the top quartile of the full sample, we assume that the firm has a unique corporate culture based on the CVF model. For example, in the case of Factor 1, which is related to adhocracy culture, we calculate the average scores for Q1, Q2, and Q3 given by the respondents of a firm in a certain year. If this average score belongs to the top $25 \%$, we apply a dummy variable, either " $\mathrm{ADHO}=1$ " 
or "ADHO $=0$ ". Similarly, for Factor 2, which is related to market culture, we calculate the average scores for Q10, Q11, and Q12, and if an average is in the top quartile, we generate "MARK = 1" or "MARK =0". Other questions such as Q4, Q5, and Q6, as well as Q8 and Q9, are classified in the same way as "CLAN $=1$ " and "HIER =1". According to this method, multiple cultures can be defined in one firm-year sample, for example, if FS1 and FS2 are both in the top $25 \%$. In that case, we define the culture (assign it 1) with a higher factor score; otherwise it is assigned 0. In addition, if a company has generally lower scores for all four cultures, then it may not have a dominant culture. Thus, we reexamine previous results by using continuous variables in the additional test section. Specifically, rather than using dummy variables, we use factor scores formed as continuous variables (FS1, FS2, FS3, FS4). By doing so, all sample firms can reveal their relatively stronger or weaker cultural tendencies. We report the results using these factor scores in the additional tests.

\subsection{Proxy of Life Cycle Stage}

Ref. [25] conducts the first study using accounting variables to measure life cycle stages. They classify life cycle stage by applying four descriptors, which are the median values of dividend propensity $(D P)$, sales growth $(S G)$, capital expenditure ratio $(C E V)$, and firm age $(A G E)$. Recent studies modify the model by including market-to-book $(M B)$ ratio in the model of Ref. [25] to measure a firm's growth rate (e.g., Ref. [48]). Ref. [26] substitutes earned equity to common equity ratio for dividend propensity. Ref. [27] additionally propose the growth of employees. Based on these studies, we select five variables to measure life cycle stages. Since Korean firms rarely pay dividends, we use earned equity to common equity ratio for dividend payment [26]. To summarize, the followings are used as indicators for measuring the life cycle stages of the firms: sales growth (SGW), fixed-asset growth $(F G W)$, employee growth $(E G W)$, earned equity to total common equity $(E Q)$, and market-to-book ratio $(M B)$.

To control volatility for each variable, we use the median of each variable for the last five years. We group the samples by the same industry and year and divide them into tertiles according to the magnitude of each variable within the group. The scores are presented in Table 3.

Table 3. Generating life cycle stages: distribution of scores by indicators.

\begin{tabular}{cccccc}
\hline Variable & SGW & FGW & EGW & EQ & MB \\
\hline Rank & 0 & 0 & 0 & 2 & 0 \\
\hline 1 of 3 tertile (high) & 1 & 1 & 1 & 1 & 1 \\
\hline 3 of 3 tertile (middle) & 2 & 2 & 2 & 0 & 2 \\
\hline
\end{tabular}

Scores from 0 to 2 are given for each firm-year observation. The life cycle score (LC_Score) is calculated by aggregating scores from the five indicators. Thus, each observation could receive a score from 0 to 10 . We classify samples as being under the growth stage if the firms have an LC_Score of less than 4, the maturity stage if they have a score between 4 and 6 , and the decline stage if they have a score greater than 6 .

\subsection{Multivariate Regression Model}

\subsubsection{Model for Testing Hypothesis 1}

To examine Hypothesis 1, we use an ordinary least square regression model. In Equation (1), our dependent variable is Tobin's Q (TQ), which is widely used to proxy firm value. It represents the long-term prospects of firm performance as perceived by market investors. To mitigate the effects of industries, we also use $T Q$ adjusted by industry (Adj_TQ), which is calculated by subtracting the median $T Q$ of the firms belonging to the same industry-year group from $T Q$. The following Equation (1) is used to examine our first hypothesis. 


$$
\begin{gathered}
T Q_{i, t}=\beta_{0}+\beta_{1} \text { CorporateCulture }_{i, t}+\beta_{2} \text { SIZE }_{i, t}+\beta_{3} \mathrm{LEV}_{i, t}+\beta_{4} \mathrm{GRW}_{i, t}+\beta_{5} \mathrm{ROA}_{i, t}+\beta_{6} \mathrm{CFO}_{i, t}+\beta_{7} P P E_{i, t}+\beta_{8} \mathrm{FORN}_{i, t} \\
+\beta_{9} \mathrm{OWN}_{i, t}+\beta_{10} \text { RISK }_{i, t}+\beta_{11} A G E_{i, t}+\text { Year fixed effects }+ \text { Industry fixed effects }
\end{gathered}
$$

CorporateCulture is the variable of interest. It consists of corporate culture variables, such as $A D H O, M A R K, C L A N$, and HIER. If adhocracy culture $(A D H O)$ has a positive coefficient for firm value, $\beta_{1}$ is both significant and positive. Likewise, if market and clan culture (MARK, CLAN) have an insignificant impact on firm value, $\beta_{1}$ will not have a statistically significant coefficient. If hierarchy culture (HIER) negatively affects firm value, $\beta_{1}$ will be negative for HIER.

We use SIZE, LEV , GRW, ROA, CFO, PPE, FORN, OWN, RISK, and AGE as control variables [49-53]. To control for the firm size and complexity, the natural logarithm of total assets (SIZE) is included. $L E V$, the ratio of total liabilities to total assets, is included to control for a firm's financial structure $[49,50]$. To control the effect of a firm's growth rate on firm value, sales growth rate $(G R W)$ is included. Higher operating profit and cash flow are positively related to the firm value [51]. We thereby include $R O A$ and CFO, where $R O A$ is the net income scaled by total assets, and CFO is cash flow from operations scaled by total assets. These variables are also used to control for the accrual- and cash-based firm performance. PPE is used to control for a firm's capital intensity, and it is calculated as depreciable assets (tangible assets except for land and construction in progress) scaled by total assets. Firms with good governance mechanisms may show higher equity values [52]. To control for governance structure, FORN and OWN are used, which are the shares held by the foreign and largest shareholders divided by total shares outstanding, respectively. RISK is equal to the standard deviation of operating income for the last five years, and is used to control for variability in operation. A previous study documents that firms lose their values as they age [53]. We thus include $A G E$, which is the natural logarithm of firm age. Finally, we use year and industry dummy variables to control for the year- and industry-specific effects.

\subsubsection{Model for Testing Hypothesis 2}

To examine Hypothesis 2, we present Equation (2) by adding the interaction terms of CorporateCulture $\times$ LC_G and CorporateCulture $\times L C \_M$ from Equation (1).

$T Q_{i, t}=\beta_{0}+\beta_{1}$ CorporateCulture $_{i, t}+\beta_{2}$ CorporateCulture $_{i, t} \times L C_{-} G_{i, t}+\beta_{3}$ CorporateCulture $_{i, t} \times L C_{-} M_{i, t}+\beta_{4} L C_{-} G_{i, t}+\beta_{5} L C_{-} M_{i, t}+$ Controls $+Y e a r$ fixed effects + Industry fixed effects

The coefficient of CorporateCulture $\left(\beta_{1}\right)$ shows the effect of the decline stage as a control group. We expect that the effects of adhocracy and clan cultures will increase when the firm is in a growth stage ( $\left.L C_{-} G\right)$ compared to a decline stage. Thus, $\beta_{2}$ will be positively significant for the two types of culture. We do not expect the other types of culture to positively impact firm value when the firm is in a maturity $\left(L C_{-} M\right)$ or decline stage. $\beta_{1}$ and $\beta_{3}$ should thus show insignificant coefficients. Furthermore, to examine the effects of overall corporate culture in each life cycle, we conduct an F-test by totaling the coefficients of the interaction values.

\subsection{The Sample}

We analyze data from the HCCP surveys in the years 2011, 2013, and 2015. As described earlier, the survey is conducted every two years. In addition, it uses companies listed in the Korea Composite Stock Price Index (KOSPI) and Korean Securities Dealers Automated Quotation (KOSDAQ) markets. The data of financial statements and stock prices are collected from the KIS-Value database of NICE Information Service Co., Ltd. The equity data are collected from the TS-2000 database of the Korea Listed Companies' Association. In order to ensure the comparability of the financial statements, we exclude companies who mainly operate in financial business and have fiscal years ending not in December. 
The descriptive statistics of the main variables are given in Table 4 . The corporate culture variables ( $A D H O, M A R K, C L A N$, and HIER) are slightly higher than 3, which is similar to the variables used in prior corporate culture studies using 5-item Likert scales [10]. About $15 \%, 48 \%$, and $38 \%$ of the samples are in the growth stage, mature stage, and decline stage, respectively. This distribution of samples is similar to that of prior studies on the life cycles of Korean firms that used the methodology of Ref. [25].

Table 4. Descriptive statistics.

\begin{tabular}{ccccccccc}
\hline Variables & $\mathbf{N}$ & Mean & Std & Min & Q1 & Median & Q3 & Max \\
\hline TQ & 528 & 1.189 & 0.814 & 0.433 & 0.784 & 0.966 & 1.271 & 7.446 \\
\hline Adj_TQ & 528 & 0.073 & 0.751 & -1.510 & -0.279 & -0.063 & 0.188 & 5.992 \\
\hline FS1(ADHO) & 528 & 3.336 & 0.347 & 2.111 & 3.134 & 3.333 & 3.542 & 4.929 \\
\hline FS2(MARK) & 528 & 3.547 & 0.330 & 2.172 & 3.333 & 3.547 & 3.747 & 4.869 \\
\hline FS3(CLAN) & 528 & 3.404 & 0.252 & 2.174 & 3.250 & 3.410 & 3.542 & 4.540 \\
\hline FS4(HIER) & 528 & 3.526 & 0.289 & 2.333 & 3.333 & 3.526 & 3.704 & 4.905 \\
\hline LC_G & 510 & 0.151 & 0.358 & 0.000 & 0.000 & 0.000 & 0.000 & 1.000 \\
\hline LC_M & 510 & 0.475 & 0.500 & 0.000 & 0.000 & 0.000 & 1.000 & 1.000 \\
\hline LC_D & 510 & 0.375 & 0.484 & 0.000 & 0.000 & 0.000 & 1.000 & 1.000 \\
\hline SIZE & 528 & 26.145 & 1.308 & 23.326 & 25.252 & 25.914 & 26.780 & 30.374 \\
\hline LEV & 528 & 0.417 & 0.186 & 0.040 & 0.262 & 0.435 & 0.557 & 0.932 \\
\hline GRW & 528 & 0.071 & 0.377 & -0.719 & -0.069 & 0.042 & 0.126 & 3.905 \\
\hline ROA & 528 & 0.026 & 0.079 & -0.472 & 0.006 & 0.028 & 0.062 & 0.274 \\
\hline PPE & 528 & 0.056 & 0.076 & -0.252 & 0.011 & 0.050 & 0.091 & 0.466 \\
\hline FORN & 528 & 0.173 & 0.118 & 0.001 & 0.086 & 0.153 & 0.240 & 0.626 \\
\hline OWN & 528 & 0.072 & 0.107 & 0.000 & 0.004 & 0.021 & 0.104 & 0.578 \\
\hline RISK & 528 & 0.415 & 0.155 & 0.044 & 0.305 & 0.414 & 0.518 & 0.848 \\
\hline AGE & 528 & 0.049 & 0.076 & 0.004 & 0.017 & 0.030 & 0.056 & 0.905 \\
\hline CorpOrate & 528 &
\end{tabular}

Corporate culture variables ( $A D H O, M A R K, C L A N, H I E R)$ are presented in continuous values, which are the mean value of each factor score.

Table 5 shows the correlations among the variables. $T Q$ and $A d j \_T Q$ are positively correlated with $A D H O$, which means that adhocracy culture positively affects firm value. $M A R K$ and CLAN are uncorrelated or weakly correlated with TQ and Adj_TQ. On the other hand, as expected, $T Q$ and $A d j \_T Q$ are negatively correlated with HIER, which means that hierarchy culture may negatively affect firm value. LC_SCORE is negatively correlated with TQ and $A d j \_T Q$, thus firm value decreases as the life cycles shifts from the growth (low LC_SCORE) to the decline stage (high LC_SCORE). Next, adhocracy culture is negatively correlated with LC_SCORE, while market and clan cultures are not. In contrast, hierarchy culture is positively correlated with LC_SCORE. These results imply that corporate culture can be changed over a firm's life cycle stages.

Table 5. Correlations among firm value, culture, and life cycle variables.

\begin{tabular}{cccccccc}
\hline Variables & TQ & A_TQ & ADHO & MARK & CLAN & HIER & LC SCORE \\
\hline \multirow{2}{*}{ TQ } & \multirow{2}{*}{1.00} & 0.75 & 0.09 & 0.04 & 0.01 & -0.12 & -0.54 \\
& & $0.00^{* * *}$ & $0.05^{*}$ & 0.32 & 0.84 & $0.01^{* *}$ & $0.00^{* * *}$ \\
\hline \multirow{2}{*}{ Adj_TQ } & \multirow{2}{*}{1.00} & $0.12^{* * *}$ & 0.08 & 0.08 & -0.06 & -0.44 \\
& & & $0.00^{* *}$ & $0.05^{*}$ & 0.14 & $0.00^{* * *}$ \\
\hline
\end{tabular}


Table 5. Cont.

\begin{tabular}{|c|c|c|c|c|c|c|c|}
\hline Variables & $T Q$ & $A \_T Q$ & ADHO & MARK & CLAN & HIER & LC SCORE \\
\hline \multirow{2}{*}{$A D H O$} & & & 1.00 & 0.57 & 0.47 & 0.06 & -0.10 \\
\hline & & & & $0.00^{* * *}$ & $0.00 * * *$ & 0.16 & $0.02 * *$ \\
\hline \multirow{2}{*}{ MARK } & & & & 1.00 & 0.44 & 0.18 & -0.05 \\
\hline & & & & & $0.00^{* * *}$ & $0.00^{* * *}$ & 0.21 \\
\hline \multirow{2}{*}{ CLAN } & & & & & 1.00 & 0.24 & -0.01 \\
\hline & & & & & & $0.00^{* * *}$ & 0.90 \\
\hline \multirow{2}{*}{ HIER } & & & & & & 1.00 & 0.14 \\
\hline & & & & & & & $0.00^{* * *}$ \\
\hline LC_SCORE & & & & & & & 1.00 \\
\hline
\end{tabular}

Spearman correlation coefficients are shown in the upper right side of the table. $p$-values are shown in the second row of each variable $\left.{ }^{*} p<0.1 ;{ }^{* *} p<0.05 ;{ }^{* *} p<0.01\right)$.

\section{Empirical Results}

\subsection{Types of Corporate Culture and Firm Value (H1)}

Table 6 shows the results of a multivariate analysis for $\mathrm{H} 1 \mathrm{using}$ Equation (1) to examine whether different types of corporate culture (measured by $A D H O, M A R K, C L A N$, and $H I E R$ ) have different effects on firm value (measured by $T Q, A d j \_T Q$ ). First, we find that the coefficient of $A D H O$ is statistically significant and positively related with both $T Q$ and Adj_TQ (coefficients $=0.146,0.164$ ), meaning that adhocracy culture positively affects firm value. Second, the coefficients of MARK and CLAN are insignificant (coefficients $=0.017$, 0.039 for MARK and coefficients $=0.089,0.102$ for $C L A N)$, which implies that market and clan cultures do not have sufficient effects on firm value. Third, the coefficient of HIER is statistically significant and negatively related to both $T Q$ and $A d j+T Q$ (coefficients $=-0.128$, -0.130 ), which suggests that hierarchy culture affects firm value negatively, all supporting $\mathrm{H} 1$.

Collectively, these results provide sufficient evidence to support H1a, H1b, and H1c. We thus conclude that corporate culture has a different effect on firm value. Moreover, as adhocracy culture is the only culture that is flexible and externally oriented, and is positively significant, we interpret this result as suggesting that this feature of firm culture can positively influence firm value.

\subsection{The Effects of Life Cycle Stage on the Relation Between Corporate Culture and Firm Value (H2)}

Table 7 shows the results of a multivariate analysis for $\mathrm{H} 2$ using Equation (2). It reports evidence on whether the incremental effect of corporate cultures (as measured by $A D H O$, $M A R K, C L A N$, and HIER) on firm value (as measured by $T Q, A d j=T Q$ ) vary at different life cycle stages (as measured by $L C_{-} G, L C \_M$ ). First, we find that the coefficients of $A D H O$ are insignificant (coefficients $=0.064$ and 0.077 for $T Q$ and $A d j \_T Q$, respectively). Since it captures the effect of a decline-stage firm's culture on firm value, it shows that being a firm at this stage with $A D H O$ culture has no impact on its value. Nevertheless, the coefficients of $A D H O \times L C \_G$ are statistically significant and positively related (coefficients $=0.430$ and 0.403 for $T Q$ and $A d j \_T Q$, respectively). In contrast, the coefficients of $A D H O \times L C_{-} M$ are insignificant (coefficients $=-0.067$ and -0.044 for $T Q$ and $A d j \_T Q$, respectively). In order to analyze the effect of corporate culture type on firm value separately for each life cycle stage, we conducted an F-test considering the incremental effects of the growth and mature stage as separate from decline stage. Only the coefficient of the growth stage is statistically significant and positive, while the F-values in the mature are insignificant. These results indicate that adhocracy culture positively affects firm value in the growth stage and not in other stages. Furthermore, it can be interpreted that it is not the culture itself but the joint effect of culture and life cycle that affects firm value. 
Table 6. Results of testing the effect of corporate culture on value (Hypothesis 1).

\begin{tabular}{|c|c|c|c|c|c|c|c|c|c|c|c|c|c|c|c|c|c|c|c|c|c|c|c|c|}
\hline \multirow{4}{*}{$\begin{array}{c}\text { Independent } \\
\text { Variable }\end{array}$} & \multicolumn{6}{|c|}{ Culture $=A D H O$} & \multicolumn{6}{|c|}{ Culture $=$ MARK } & \multicolumn{6}{|c|}{ Culture $=C L A N$} & \multicolumn{6}{|c|}{ Culture $=$ HIER } \\
\hline & \multicolumn{3}{|c|}{$D e p=T Q$} & \multicolumn{3}{|c|}{$D e p=A d j \_T Q$} & \multicolumn{3}{|c|}{$D e p=T Q$} & \multicolumn{3}{|c|}{$D e p=A d j_{-} T Q$} & \multicolumn{3}{|c|}{$D e p=T Q$} & \multicolumn{3}{|c|}{$D e p=A d j_{-} T Q$} & \multicolumn{3}{|c|}{$D e p=T Q$} & \multicolumn{3}{|c|}{$D e p=A d j \_T Q$} \\
\hline & \multirow{2}{*}{$\frac{\beta}{4.772}$} & \multicolumn{2}{|c|}{ t-Value } & \multirow{2}{*}{$\begin{array}{c}\beta \\
2.880\end{array}$} & \multicolumn{2}{|c|}{ t-Value } & \multirow{2}{*}{$\frac{\beta}{4.472}$} & \multicolumn{2}{|c|}{ t-Value } & \multirow{2}{*}{$\begin{array}{c}\beta \\
2.586\end{array}$} & \multicolumn{2}{|c|}{ t-Value } & \multirow{2}{*}{$\begin{array}{c}\beta \\
4.695\end{array}$} & \multicolumn{2}{|c|}{ t-Value } & \multirow{2}{*}{$\begin{array}{c}\beta \\
2.800\end{array}$} & \multicolumn{2}{|c|}{ t-Value } & \multirow{2}{*}{$\frac{\beta}{4.450}$} & \multicolumn{2}{|c|}{ t-Value } & $\beta$ & $t-V a$ & \\
\hline & & 5.56 & $* * *$ & & 3.41 & $* * *$ & & 5.19 & $* * *$ & & 3.04 & $* * *$ & & 5.39 & $* * *$ & & 3.26 & $* * *$ & & 5.28 & $* * *$ & 2.516 & 3.03 & $* * *$ \\
\hline Culture & 0.146 & 2.07 & $* *$ & 0.164 & 2.36 & $* *$ & 0.017 & 0.24 & & 0.039 & 0.54 & & 0.089 & 1.21 & & 0.102 & 1.41 & & -0.128 & -1.84 & $*$ & -0.130 & -1.89 & * \\
\hline SIZE & -0.076 & -2.36 & $* *$ & -0.083 & -2.61 & $* * *$ & -0.063 & -1.95 & $*$ & -0.069 & -2.19 & $* *$ & -0.071 & -2.18 & $* *$ & -0.078 & -2.41 & $* *$ & -0.062 & -1.95 & $*$ & -0.067 & -2.14 & ** \\
\hline LEV & 0.937 & 5.24 & $* * *$ & 0.969 & 5.50 & $* * *$ & 0.902 & 5.04 & $* * *$ & 0.934 & 5.28 & $* * *$ & 0.905 & 5.07 & $* * *$ & 0.934 & 5.30 & $* * *$ & 0.863 & 4.82 & $* * *$ & 0.891 & 5.04 & $* * *$ \\
\hline GRW & 0.127 & 1.62 & & 0.091 & 1.18 & & 0.129 & 1.63 & & 0.093 & 1.19 & & 0.134 & 1.69 & * & 0.099 & 1.27 & & 0.126 & 1.60 & & 0.090 & 1.16 & \\
\hline$R O A$ & 2.498 & 5.37 & $* * *$ & 2.245 & 4.90 & $* * *$ & 2.507 & 5.37 & $* * *$ & 2.253 & 4.89 & $* * *$ & 2.476 & 5.30 & $* * *$ & 2.219 & 4.82 & $* * *$ & 2.427 & 5.19 & $* * *$ & 2.175 & 4.71 & $* * *$ \\
\hline CFO & 1.357 & 2.84 & $* * *$ & 1.597 & 3.39 & $* * *$ & 1.416 & 2.95 & $* * *$ & 1.653 & 3.49 & $* * *$ & 1.421 & 2.98 & $* * *$ & 1.669 & 3.54 & $* * *$ & 1.472 & 3.08 & $* * *$ & 1.721 & 3.66 & $* * *$ \\
\hline$P P E$ & -0.668 & -2.39 & $* *$ & -0.767 & -2.78 & $* * *$ & -0.671 & -2.38 & $* *$ & -0.773 & -2.78 & $* * *$ & -0.665 & -2.37 & $* *$ & -0.763 & -2.75 & $* * *$ & -0.648 & -2.31 & $* *$ & -0.747 & -2.70 & $* * *$ \\
\hline FORN & 1.927 & 5.25 & $* * *$ & 1.955 & 5.40 & $* * *$ & 1.860 & 5.06 & $* * *$ & 1.875 & 5.17 & $* * *$ & 1.884 & 5.13 & $* * *$ & 1.908 & 5.27 & $* * *$ & 1.908 & 5.20 & $* * *$ & 1.929 & 5.33 & $* * *$ \\
\hline OWN & -0.793 & -3.70 & $* * *$ & -0.805 & -3.81 & $* * *$ & -0.837 & -3.89 & $* * *$ & -0.858 & -4.04 & $* * *$ & -0.821 & -3.83 & $* * *$ & -0.836 & -3.95 & $* * *$ & -0.822 & -3.84 & $* * *$ & -0.838 & -3.97 & $* * *$ \\
\hline RISK & 1.705 & 4.09 & $* * *$ & 1.678 & 4.08 & $* * *$ & 1.731 & 4.13 & $* * *$ & 1.706 & 4.13 & $* * *$ & 1.744 & 4.17 & $* * *$ & 1.722 & 4.17 & $* * *$ & 1.691 & 4.05 & $* * *$ & 1.666 & 4.17 & $* * *$ \\
\hline$A G E$ & -0.267 & -3.79 & $* * *$ & -0.276 & -3.97 & $* * *$ & -0.268 & -3.77 & $* * *$ & -0.279 & -3.97 & $* * *$ & -0.269 & -3.80 & $* * *$ & -0.279 & -3.99 & $* * *$ & -0.252 & -3.55 & $* * *$ & -0.261 & -3.73 & $* * *$ \\
\hline F-value & & $8.55^{* * *}$ & & & $5.301^{* * *}$ & & & $.389^{* * *}$ & & & $.125^{* * *}$ & & & 8.443 *** & & & $6.182 * * *$ & & & $3.515^{* * *}$ & & & $.234^{* * *}$ & \\
\hline Adj_Rsq & & 0.413 & & & 0.330 & & & 0.407 & & & 0.323 & & & 0.409 & & & 0.325 & & & 0.411 & & & 0.327 & \\
\hline N_obs & & 528 & & & 528 & & & 528 & & & 528 & & & 528 & & & 528 & & & 528 & & & 528 & \\
\hline
\end{tabular}

Table 7. Results of testing the incremental effect of life cycle on the relationship between corporate culture and value (Hypothesis 2).

\begin{tabular}{|c|c|c|c|c|c|c|c|c|c|c|c|c|c|c|c|c|c|c|c|c|c|c|c|c|}
\hline \multirow{4}{*}{$\begin{array}{c}\begin{array}{c}\text { Independent } \\
\text { Variable }\end{array} \\
\text { Intercept } \\
\end{array}$} & \multicolumn{6}{|c|}{ Culture $=A D H O$} & \multicolumn{6}{|c|}{ Culture $=$ MARK } & \multicolumn{6}{|c|}{ Culture $=C L A N$} & \multicolumn{6}{|c|}{ Culture $=$ HIER } \\
\hline & \multicolumn{3}{|c|}{$D e p=T Q$} & \multicolumn{3}{|c|}{$D e p=A d j_{-} T Q$} & \multicolumn{3}{|c|}{$D e p=T Q$} & \multicolumn{3}{|c|}{$D e p=A d j_{-} T Q$} & \multicolumn{3}{|c|}{$D e p=T Q$} & \multicolumn{3}{|c|}{$D e p=A d j \_T Q$} & \multicolumn{3}{|c|}{$D e p=T Q$} & \multicolumn{3}{|c|}{$D e p=A d j_{-} T Q$} \\
\hline & \multirow{2}{*}{$\begin{array}{c}\beta \\
4.757 \\
\end{array}$} & \multicolumn{2}{|c|}{$t$-Value } & \multirow{2}{*}{$\begin{array}{c}\beta \\
2.853\end{array}$} & \multicolumn{2}{|c|}{$t$-Value } & \multirow{2}{*}{$\begin{array}{c}\beta \\
4.365\end{array}$} & \multicolumn{2}{|c|}{$t$-Value } & \multirow{2}{*}{$\begin{array}{c}\beta \\
2.487\end{array}$} & \multicolumn{2}{|c|}{ t-Value } & \multirow{2}{*}{$\frac{\beta}{4.672}$} & \multicolumn{2}{|c|}{$t$-Value } & \multirow{2}{*}{$\frac{\beta}{2.790}$} & \multicolumn{2}{|c|}{ t-Value } & \multirow{2}{*}{$\frac{\beta}{4.372}$} & \multicolumn{2}{|c|}{$t$-Value } & \multirow{2}{*}{$\begin{array}{c}\beta \\
2.436\end{array}$} & \multicolumn{2}{|c|}{ t-Value } \\
\hline & & 5.54 & $* * *$ & & 3.36 & $* * *$ & & 5.02 & $* * *$ & & 2.89 & $* * *$ & & 5.35 & $* * *$ & & 3.22 & $* * *$ & & 5.13 & $* * *$ & & 2.89 & $* * *$ \\
\hline Culture ( $\beta 1)$ & 0.064 & 0.55 & & 0.077 & 0.67 & & -0.018 & -0.16 & & 0.006 & 0.05 & & 0.030 & 0.28 & & 0.026 & 0.23 & & -0.042 & -0.41 & & -0.079 & -0.78 & \\
\hline Culture $\times$ LC_G $(\beta 2)$ & 0.430 & 2.23 & $* *$ & 0.403 & 2.11 & $* *$ & 0.164 & 0.83 & & 0.118 & 0.60 & & 0.530 & 2.68 & $* * *$ & 0.507 & 2.59 & $* * *$ & -0.018 & -0.09 & & 0.044 & 0.21 & \\
\hline Culture $\times L C \_\_M(\beta 3)$ & -0.067 & -0.45 & & -0.044 & -0.30 & & -0.030 & -0.20 & & -0.016 & -0.10 & & -0.060 & -0.41 & & -0.012 & -0.09 & & -0.138 & -0.96 & & -0.082 & -0.58 & \\
\hline
\end{tabular}


Table 7. Cont.

\begin{tabular}{|c|c|c|c|c|c|c|c|c|c|c|c|c|c|c|c|c|c|c|c|c|c|c|c|c|}
\hline \multirow{4}{*}{$\begin{array}{c}\begin{array}{c}\text { Independent } \\
\text { Variable }\end{array} \\
\text { LC_G }\end{array}$} & \multicolumn{6}{|c|}{ Culture $=A D H O$} & \multicolumn{6}{|c|}{ Culture $=$ MARK } & \multicolumn{6}{|c|}{ Culture $=C L A N$} & \multicolumn{6}{|c|}{ Culture = HIER } \\
\hline & \multicolumn{3}{|c|}{$D e p=T Q$} & \multicolumn{3}{|c|}{$D e p=A d j_{-} T Q$} & \multicolumn{3}{|c|}{$D e p=T Q$} & \multicolumn{3}{|c|}{$D e p=A d j_{-} T Q$} & \multicolumn{3}{|c|}{$D e p=T Q$} & \multicolumn{3}{|c|}{$D e p=A d j_{-} T Q$} & \multicolumn{3}{|c|}{$D e p=T Q$} & \multicolumn{3}{|c|}{$D e p=A d j \_T Q$} \\
\hline & \multirow{2}{*}{$\begin{array}{c}\beta \\
0.358\end{array}$} & \multicolumn{2}{|c|}{ t-Value } & \multirow{2}{*}{$\begin{array}{c}\beta \\
0.331\end{array}$} & \multicolumn{2}{|c|}{ t-Value } & \multirow{2}{*}{$\begin{array}{c}\beta \\
0.471\end{array}$} & \multicolumn{2}{|c|}{ t-Value } & \multirow{2}{*}{$\begin{array}{c}\beta \\
0.448\end{array}$} & \multicolumn{2}{|c|}{ t-Value } & \multirow{2}{*}{$\begin{array}{c}\beta \\
0.358\end{array}$} & \multicolumn{2}{|c|}{ t-Value } & \multirow{2}{*}{$\begin{array}{c}\beta \\
0.331\end{array}$} & \multicolumn{2}{|c|}{ t-Value } & \multirow{2}{*}{$\begin{array}{c}\beta \\
0.529\end{array}$} & $t-\mathrm{Va}$ & & $\beta$ & $t-V a$ & \\
\hline & & 3.09 & $* * *$ & & 2.89 & $* * *$ & & 4.10 & $* * *$ & & 3.94 & $* * *$ & & 3.13 & $* * *$ & & 2.93 & $* * *$ & & 4.76 & $* * *$ & 0.476 & 4.33 & $* * *$ \\
\hline$L C \_M$ & 0.287 & 3.90 & $* * *$ & 0.272 & 3.73 & $* * *$ & 0.274 & 3.66 & $* * *$ & 0.261 & 3.53 & $* * *$ & 0.287 & 3.77 & $* * * *$ & 0.267 & 3.53 & $* * *$ & 0.293 & 3.74 & $* * *$ & 0.267 & 3.45 & $* * *$ \\
\hline SIZE & -0.082 & -2.54 & $* *$ & -0.089 & -2.77 & $* * *$ & -0.066 & -2.04 & $* *$ & -0.073 & -2.28 & $* *$ & -0.082 & -2.49 & $* *$ & -0.088 & -2.72 & $* * *$ & -0.067 & -2.11 & $* *$ & -0.072 & -2.27 & ** \\
\hline$L E V$ & 0.723 & 3.91 & $* * *$ & 0.766 & 4.18 & $* * *$ & 0.660 & 3.55 & $* * *$ & 0.701 & 3.81 & $* * *$ & 0.722 & 3.86 & $* * *$ & 0.766 & 4.13 & $* * *$ & 0.624 & 3.36 & $* * *$ & 0.666 & 3.62 & $* * *$ \\
\hline GRW & 0.096 & 1.23 & & 0.064 & 0.83 & & 0.104 & 1.31 & & 0.072 & 0.91 & & 0.103 & 1.32 & & 0.071 & 0.92 & & 0.101 & 1.28 & & 0.068 & 0.86 & \\
\hline$R O A$ & 2.206 & 4.61 & $* * *$ & 1.964 & 4.14 & $* * *$ & 2.147 & 4.44 & $* * *$ & 1.899 & 3.96 & $* * *$ & 2.246 & 4.67 & $* * *$ & 1.997 & 4.19 & $* * *$ & 2.044 & 4.20 & $* * *$ & 1.829 & 3.80 & $* * *$ \\
\hline CFO & 1.049 & 2.16 & $* *$ & 1.325 & 2.76 & $* * *$ & 1.091 & 2.21 & $* *$ & 1.373 & 2.81 & $* * *$ & 1.044 & 2.16 & $* *$ & 1.326 & 2.77 & $* * *$ & 1.212 & 2.47 & $* *$ & 1.465 & 2.77 & $* * *$ \\
\hline$P P E$ & -0.771 & -2.71 & $* * *$ & -0.863 & -3.06 & $* * *$ & -0.746 & -2.60 & $* * *$ & -0.842 & -2.96 & $* * *$ & -0.673 & -2.37 & $* *$ & -0.775 & -2.75 & $* * *$ & -0.727 & -2.54 & $* *$ & -0.815 & -2.87 & $* * *$ \\
\hline FORN & 1.895 & 5.22 & $* * *$ & 1.923 & 5.35 & $* * *$ & 1.878 & 5.13 & $* * *$ & 1.889 & 5.21 & $* * *$ & 1.937 & 5.35 & $* * *$ & 1.959 & 5.45 & $* * *$ & 1.895 & 5.19 & $* * *$ & 1.912 & 5.29 & $* * *$ \\
\hline OWN & -0.611 & -2.80 & $* * *$ & -0.634 & -2.93 & $* * *$ & -0.649 & -2.94 & $* * *$ & -0.688 & -3.15 & $* * *$ & -0.604 & -2.78 & $* * *$ & -0.631 & -2.93 & $* * *$ & -0.667 & -3.04 & $* * *$ & -0.687 & -3.16 & $* * *$ \\
\hline RISK & 1.702 & 4.13 & $* * *$ & 1.674 & 4.10 & $* * *$ & 1.706 & 4.10 & $* * *$ & 1.680 & 4.07 & $* * *$ & 1.719 & 4.19 & $* * * *$ & 1.698 & 4.17 & $* * * *$ & 1.683 & 4.06 & $* * *$ & 1.659 & 4.04 & $* * *$ \\
\hline$A G E$ & -0.256 & -3.64 & $* * *$ & -0.265 & -3.80 & $* * *$ & -0.248 & -3.47 & $* * *$ & -0.258 & -3.65 & $* * *$ & -0.244 & -3.48 & $* * *$ & -0.254 & -3.65 & $* * * *$ & -0.227 & -3.18 & $* * *$ & -0.237 & -3.36 & $* * *$ \\
\hline F-value & & $8.822 * * *$ & & & 6.608 *** & & & $.471^{* * *}$ & & & $297^{* * *}$ & & & $882^{* * *}$ & & & $5.632 * * *$ & & & $.548^{* * *}$ & & & $.372 * * *$ & \\
\hline Adj_Rsq & & 0.449 & & & 0.369 & & & 0.438 & & & 0.356 & & & 0.451 & & & 0.370 & & & 0.440 & & & 0.359 & \\
\hline N_obs & & 510 & & & 510 & & & 510 & & & 510 & & & 510 & & & 510 & & & 510 & & & 510 & \\
\hline Growth: $\beta 1+\beta 2$ & & $10.14^{* * *}$ & & & $9.75^{* * *}$ & & & 0.81 & & & 0.61 & & & $1.78^{* * *}$ & & & $10.84^{* * *}$ & & & 0.10 & & & 0.03 & \\
\hline Mature: $\beta 1+\beta 3$ & & 0.00 & & & 0.11 & & & 0.20 & & & 0.01 & & & 0.07 & & & 0.02 & & & 2.83 & & & 2.40 & \\
\hline
\end{tabular}

${ }^{* *} p<0.05 ;{ }^{* * *} p<0.01$. Variable definition is presented in Section 4.3. F-values are shown in the F-tests. 
Second, the coefficient of $M A R K$ is statistically insignificant (coefficients $=-0.018$ and 0.006 for $T Q$ and $A d j \_T Q$, respectively). The coefficients of $M A R K \times L C_{-} G$ and $M A K R \times L C \_M$ are also insignificant. The F-test results show that all of the coefficients in the life cycle stages are statistically insignificant.

Third, the coefficient of CLAN is statistically insignificant (coefficients $=0.030$ and 0.026 for $T Q$ and $A d j \_T Q$, respectively). The coefficients of CLAN $\times L C \_G$ are statistically significant and positive. However, CLAN $\times L C \_M$ is insignificant. Similarly, we conducted an F-test considering the incremental effects of growth and mature stage separately from decline stage. Only the coefficient in the growth stage is statistically significant and positively related. The F-values are not significant for the maturity and decline stages (in the case of the decline stage, the significance can be identified by $\beta_{1}$ itself). These results are similar to those of adhocracy culture, suggesting that CLAN culture has a positive effect on firm value in the growth stage and not in the other stages.

Finally, the coefficients of HIER, HIER $\times$ LC_G and HIER $\times$ LC_M are generally negative but statistically insignificant. As shown in the F-tests, the coefficients in all the life cycle stages are statistically insignificant.

Collectively, the results in Table 7 support H2. We thus document that the effects of each type of corporate culture on firm value depend on a firm's life cycle stage. Specifically, the growth stage, which is known to feature dynamic environmental changes and a flexible culture, such as adhocracy and clan culture, has an incremental positive effect on firm value.

\subsection{Additional Tests}

\subsubsection{Mitigating the Endogeneity Concern}

Thus far, we have proposed evidence of the effect of culture on firm value. This finding may suffer from endogeneity, the possibility that the causal relationship is reversed, and that firm value actually determines the firm's culture. To mitigate this concern, we apply the lead-lag regression that is widely used to fixate the causality among the variables. Specifically, we apply a one-year-ahead firm value proxy $\left(A d j \_T Q_{t+1}\right)$ to the current firm cultures.

The results of this additional analysis are presented in Table 8 . When using this lead-lag method, we obtain the same results as the previous findings. For instance, the coefficient of Culture is positive and significant when it refers to $A D H O$. We find that clan culture is also positively related to firm value, showing that the flexibility and discretion are important features of culture that affect firm value. In contrast, the coefficient of HIER is negatively significant. Although untabulated, the results using $T Q_{t+1}$ are similar to the reported findings. Thus, we document that our findings are not derived by the possible reverse relation between culture and firm value.

Table 8. Mitigating endogeneity: test results of lead-lag regression.

\begin{tabular}{|c|c|c|c|c|c|c|c|c|c|c|c|c|}
\hline \multirow{4}{*}{$\begin{array}{c}\text { Independent } \\
\text { Variables }\end{array}$} & \multicolumn{12}{|c|}{$D e p=A d j \_T Q_{t+1}$} \\
\hline & \multicolumn{3}{|c|}{ Culture $=A D H O$} & \multicolumn{3}{|c|}{ Culture $=$ MARK } & \multicolumn{3}{|c|}{ Culture $=$ CLAN } & \multicolumn{3}{|c|}{ Culture = HIER } \\
\hline & \multirow{2}{*}{$\begin{array}{c}\beta \\
5.274\end{array}$} & \multicolumn{2}{|c|}{ t-Value } & \multirow{2}{*}{$\begin{array}{c}\beta \\
4.949\end{array}$} & \multicolumn{2}{|c|}{ t-Value } & \multirow{2}{*}{$\begin{array}{c}\beta \\
5.207\end{array}$} & \multicolumn{2}{|c|}{ t-Value } & \multirow{2}{*}{$\begin{array}{c}\beta \\
4.855\end{array}$} & \multicolumn{2}{|c|}{ t-Value } \\
\hline & & 6.25 & $* * *$ & & 5.82 & $* * *$ & & 6.05 & $* * *$ & & 5.82 & $* * *$ \\
\hline Culture & 0.200 & 2.87 & $* * *$ & 0.057 & 0.78 & & 0.129 & 1.78 & $*$ & -0.130 & -1.88 & $*$ \\
\hline Controls & \multicolumn{3}{|c|}{ Included } & \multicolumn{3}{|c|}{ Included } & \multicolumn{3}{|c|}{ Included } & \multicolumn{3}{|c|}{ Included } \\
\hline Fixed Effects & \multicolumn{3}{|c|}{ Included } & \multicolumn{3}{|c|}{ Included } & \multicolumn{3}{|c|}{ Included } & \multicolumn{3}{|c|}{ Included } \\
\hline F-value & \multicolumn{3}{|c|}{$5.946^{* * *}$} & \multicolumn{3}{|c|}{$5.779 * * *$} & \multicolumn{3}{|c|}{$5.696^{* * *}$} & \multicolumn{3}{|c|}{$6.093^{* * *}$} \\
\hline Adj_Rsq & \multicolumn{3}{|c|}{0.311} & \multicolumn{3}{|c|}{0.303} & \multicolumn{3}{|c|}{0.300} & \multicolumn{3}{|c|}{0.321} \\
\hline N_obs & \multicolumn{3}{|c|}{528} & \multicolumn{3}{|c|}{528} & \multicolumn{3}{|c|}{528} & \multicolumn{3}{|c|}{528} \\
\hline
\end{tabular}




\subsubsection{Other Sensitivity Test}

We also performed a sensitivity test to check the robustness of our findings. In our main model, we define the corporate culture indicator as the top quartile of each factor score in each of the samples. The effects of corporate culture that we have analyzed so far would be sensitive to this classification. We thus change each corporate culture variable previously formed as a dummy variable (ADHO, CLAN, MARK, HIER) into a factor score, itself formed as a continuous variable (FS1, FS2, FS3, FS4). As we previously described in the research design section, FS1 to FS4 respectively represent the four types of culture: adhocracy, market, clan, and hierarchy culture.

The results are presented in Table 9. The purposes of this table are twofold. First, we include all culture variables in one regression to test the effect of a certain culture on firm value after controlling for other cultures. Even if there are companies with more than one culture, including all cultures in one regression can reveal all the effects of each cultural characteristic on firm value. Second, as we discussed above, we use continuous variables rather than the dummy indicators. Unlike the top 25\% classification, all sample companies could show specific cultural tendencies under these continuous variables.

Table 9. Sensitivity test: including all cultures and using continuous variables of cultures.

\begin{tabular}{|c|c|c|c|c|c|c|c|c|c|c|c|c|}
\hline \multirow{4}{*}{$\begin{array}{c}\text { Independent } \\
\text { Variables }\end{array}$} & \multicolumn{6}{|c|}{ All Cultures in One Regression } & \multicolumn{6}{|c|}{ Using Continuous Culture Variables } \\
\hline & \multicolumn{3}{|c|}{$D e p=T Q$} & \multicolumn{3}{|c|}{$D e p=A d j \_T Q$} & \multicolumn{3}{|c|}{$D e p=T Q$} & \multicolumn{3}{|c|}{$D e p=A d j \_T Q$} \\
\hline & \multirow{2}{*}{$\frac{\beta}{4.866}$} & \multicolumn{2}{|c|}{ t-Value } & \multirow{2}{*}{$\frac{\beta}{3.000}$} & \multicolumn{2}{|c|}{ t-Value } & \multirow{2}{*}{$\frac{\beta}{5.610}$} & \multicolumn{2}{|c|}{ t-Value } & \multirow{2}{*}{$\begin{array}{c}\beta \\
3.675\end{array}$} & \multicolumn{2}{|c|}{ t-Value } \\
\hline & & 5.57 & $* * *$ & & 3.48 & $* * *$ & & 6.18 & $* * *$ & & 4.10 & $* * *$ \\
\hline$A D H O$ & 0.153 & 1.80 & * & 0.162 & 1.94 & * & & & & & & \\
\hline$M A R K$ & -0.067 & -0.77 & & -0.050 & -0.59 & & & & & & & \\
\hline CLAN & 0.070 & 0.83 & & 0.073 & 0.88 & & & & & & & \\
\hline HIER & -0.138 & -1.94 & * & -0.143 & -2.04 & $* *$ & & & & & & \\
\hline FS1 & & & & & & & 0.341 & 2.26 & $* *$ & 0.331 & 2.22 & ** \\
\hline FS2 & & & & & & & -0.222 & -1.24 & & -0.155 & -0.87 & \\
\hline FS3 & & & & & & & 0.085 & 0.64 & & 0.043 & 0.32 & \\
\hline FS4 & & & & & & & -0.454 & -3.25 & $* * *$ & -0.471 & -3.42 & $* * *$ \\
\hline Controls & & Included & & & Included & & & Included & & & Included & \\
\hline Fixed Effects & & Included & & & Included & & & Included & & & Included & \\
\hline F-value & & $8.180^{* * *}$ & & & $6.058^{* * *}$ & & & $8.752^{* * *}$ & & & $6.530 * * *$ & \\
\hline Adj_Rsq & & 0.415 & & & 0.333 & & & 0.433 & & & 0.353 & \\
\hline N_obs & & 528 & & & 528 & & & 528 & & & 528 & \\
\hline
\end{tabular}

${ }^{*} p<0.1 ; * *<0.05 ;{ }^{* * *} p<0.01$. Variable definition is presented in Section 4.3.

As can be seen in the table, we observe results that are consistent with our previous findings. In the first and second columns, we document that $A D H O$ culture has a positive impact on firm value, while HIER culture is negatively related to firm value. Similarly, in the third and fourth columns, FS1 and FS4 show positive and negative coefficients, respectively. Thus, we interpret these findings as suggesting that our results are robust in cases that include all cultures in one regression, and those that use the raw values of the data from the questionnaires.

\section{Discussion and Conclusions}

In this study, by using data from HCCP surveys, we find a systematic relationship between firms' cultures and their value. In particular, adhocracy culture has a positive impact on firm value, while hierarchy culture has a negative impact on it. Moreover, we find that the effect of corporate culture on firm value varies at different life cycle stages. 
For instance, firms in the growth stage have a positive incremental effect on firm value when their cultures are either adhocracy or clan.

Our findings shed light on the prior literature in the following ways. First, previous studies document that each firm embodies its own corporate culture $[7,23,24]$. Nevertheless, there is still a lack of empirical research concerning whether and how a firm's culture affects its value $[19,22]$. For instance, some previous studies suffer from the discretion in the classification of cultural types. We mitigate this by applying survey data conducted by the national institute. The findings of our study reveal that a firm's culture is an important determinant of its value. In particular, the culture that offers flexibility and discretion to employees and makes them focus more on external activities positively impacts firm value more significantly than the other cultures, which is not documented well in prior research.

Secondly, another caveat of previous studies is that they implicitly assume that a firm's culture does not vary over time $[23,24]$. Few studies have so far directly linked corporate culture to the environmental changes of a firm. Furthermore, studies generally assume that the environmental changes are sequential in nature, representing a hierarchical progression that is not easily reversible. To fill this void, by applying a life cycle as a proxy for the environmental change of the firm, we investigate and provide insight into the literature, finding that the impact of corporate culture may vary by the stage it belongs to. Moreover, our study contributes to the existing literature by exploring the possibility that the impact of corporate culture on a firm's value would vary with changes in the life cycle stages.

The findings of our study call for future research. First, so far, few studies have directly addressed the relationship between a firm's life cycle and its culture. It would be necessary for future studies to expand our study and investigate how cultural differences in enterprises affect their other decisions and outcomes, such as financing, tax planning, or non-financial reporting. Second, studies generally assume that the life cycle stages are not easily reversible. Our study mitigates this by exploring the possibility that the impact of corporate culture would vary with changes in the life cycle stages. The finding that not only culture, but a joint effect of culture and life cycle stage, enhances firm value suggests that future research needs to focus on dynamic changes in the corporate environment.

Our study offers the following practice and policy implications. First, the finding that adhocracy culture and hierarchy culture have opposite impacts on firm value suggest a practical insight. For instance, firms in a hierarchy culture should change their culture to a more flexible and externally oriented one. The culture should focus more on entrepreneurship, creativity, and adaptability. Second, evidence that cultures have a positive incremental effect on firm value when the firm is in its growth stage provides policy implications. It stresses that firms in later stages should respond appropriately to environmental changes by adopting alternative routines. Regulatory supports are needed in order to make later-stage firms have less resistance to change and innovation. On the other hand, policies that support their entrepreneurial activities are required for firms in the early stage.

Author Contributions: Conceptualization, S.O.P.; methodology, S.T.K. and H.J.N.; investigation, S.T.K.; data curation, H.J.N.; writing—original draft preparation, S.U.C.; writing—review and editing, S.O.P. and S.U.C. All authors have read and agreed to the published version of the manuscript.

Funding: This work was supported by the Ministry of Education of the Republic of Korea and the National Research Foundation of Korea (NRF-2018S1A5A2A03036394).

Institutional Review Board Statement: Not applicable.

Informed Consent Statement: Not applicable.

Data Availability Statement: The data presented in this study are openly available from the sources reported in the paper.

Conflicts of Interest: The authors declare no conflict of interest. 


\section{Appendix A}

Table A1. Questionnaires to define corporate culture.

\begin{tabular}{cr}
\hline Item & Content \\
\hline Q1 & Our company encourages change and new initiatives. \\
Q2 & Our company compensates for innovation adequately. \\
Q3 & Our company treats creative workers more than diligent workers. \\
Q4 & Our company has a family-like atmosphere. \\
Q5 & Our company emphasizes cohesion and unity. \\
Q6 & Our company emphasizes teamwork. \\
Q7 & Our company takes formal procedures, rules and policies seriously. \\
Q8 & The communication and information flow in our company is "top-down". \\
Q9 & Our company emphasizes hierarchical consciousness in organization. \\
Q10 & Our company emphasizes competitive sense and achievement. \\
Q11 & Our company values the expertise and ability to carry out tasks. \\
Q12 & Our company evaluates workers based on ability and performance. \\
\hline
\end{tabular}

\section{References}

1. Miron, E.; Erez, M.; Naveh, E. Do personal characteristics and cultural values that promote innovation, quality, and efficiency compete or complement each other? J. Organ. Behav. 2004, 25, 175-199. [CrossRef]

2. Gregory, B.T.; Harris, S.G.; Armenakis, A.A.; Shook, C.L. Organizational culture and effectiveness: A study of values, attitudes, and organizational outcomes. J. Bus. Res. 2009, 62, 673-679. [CrossRef]

3. Chan, L.L.; Shaffer, M.A.; Snape, E. In search of sustained competitive advantage: The impact of organizational culture, competitive strategy and human resource management practices on firm performance. Int. J. Hum. Resour. Manag. 2004, 15, 17-35. [CrossRef]

4. Yesil, S.; Kaya, A. The effect of organizational culture on firm financial performance: Evidence from a developing country. Procedia-Soc. Behav. Sci. 2013, 81, 428-437. [CrossRef]

5. Naranjo-Valencia, J.C.; Jiménez-Jiménez, D.; Sanz-Valle, R. Studying the links between organizational culture, innovation, and performance in Spanish companies. Rev. Latinoam. Psicol. 2016, 48, 30-41. [CrossRef]

6. Kotrba, L.M.; Gillespie, A.M.; Schmidt, A.M.; Smerek, E.R.; Ritchie, A.S.; Denison, D.R. Do consistent corporate cultures have better business performance? Exploring the interaction effects. Hum. Relat. 2012, 65, 241-262. [CrossRef]

7. Hogan, S.J.; Coote, L.V. Organizational culture, innovation, and performance: A test of Schein's model. J. Bus. Res. 2014, 67, 1609-1621. [CrossRef]

8. Prajogo, D.I.; McDermott, C.M. The relationship between multidimensional organizational culture and performance. International. Int. J. Oper. Prod. Manag. 2011, 7,712-735. [CrossRef]

9. Groysberg, B.; Lee, J.; Price, J.; Cheng, J. The leader's guide to corporate culture. Harv. Bus. Rev. 2018, 96, 44-52.

10. Bolton, P.; Brunnermeier, M.K.; Veldkamp, L. Leadership, coordination, and corporate culture. Rev. Econ. Stud. 2012, 80, 512-537. [CrossRef]

11. Zheng, W.; Yang, B.; McLean, G.N. Linking organizational culture, structure, strategy, and organizational effectiveness: Mediating role of knowledge management. J. Bus. Res. 2010, 7, 763-771. [CrossRef]

12. Naranjo-Valencia, J.C.; Jiménez-Jiménez, D.; Sanz-Valle, R. Innovation or imitation? The role of organizational culture. Manag. Decis. 2011, 49, 55-72. [CrossRef]

13. Tsai, Y. Relationship between organizational culture, leadership behavior and job satisfaction. BMC Health Serv. Res. 2011, 11, 98. [CrossRef]

14. Lok, P.; Crawford, J. The effect of organisational culture and leadership style on job satisfaction and organisational commitment. J. Manag. Dev. 2004, 4, 321-338. [CrossRef]

15. Tseng, S.M. The correlation between organizational culture and knowledge conversion on corporate performance. J. Knowl. Manag. 2010, 2, 269-284. [CrossRef]

16. Bell DeTienne, K.; Dyer, G.; Hoopes, C.; Harris, S. Toward a model of effective knowledge management and directions for future research: Culture, leadership, and CKOs. J. Leadersh. Organ. Stud. 2004, 4, 26-43. [CrossRef]

17. Belak, J. Management and governance: Organizational culture in relation to enterprise life cycle. Kybernetes 2016, 45, 680-698. [CrossRef]

18. Bodie, Z. Thoughts on the future: Life-cycle investing in theory and practice. Financ. Anal. J. 2015, 1, 43-48. [CrossRef]

19. Cordes, C.; Richerson, P.J.; Schwesinger, G. How corporate cultures coevolve with the business environment: The case of firm growth crises and industry evolution. J. Econ. Behav. Organ. 2010, 76, 465-480. [CrossRef]

20. Dickinson, V. Cash flow patterns as a proxy for firm life cycle. Account. Rev. 2011, 86, 1969-1994. [CrossRef]

21. Hasan, M.M.; Habib, A. Firm life cycle and idiosyncratic volatility. Int. Rev. Financ. Anal. 2017, 50, 164-175. [CrossRef] 
22. Hiller, V.; Verdier, T. Corporate culture and identity investment in an industry equilibrium. J. Econ. Behav. Organ. 2014, 103, 93-112. [CrossRef]

23. Quinn, R.E.; Cameron, K. Organizational life cycles and shifting criteria of effectiveness: Some preliminary evidence. Manag. Sci. 1983, 1, 33-51. [CrossRef]

24. Cameron, K.S.; Quinn, R.E. Diagnosing and Changing Organizational Culture: Based on the Competing Values Frame-Work; John Wiley \& Sons: San Francisco, CA, USA, 2011.

25. Anthony, J.H.; Ramesh, K. Association between accounting performance measures and stock prices: A test of the life cycle hypothesis. J. Account. Econ. 1992, 15, 203-227. [CrossRef]

26. DeAngelo, H.; Stulz, R.M. Dividend policy and the earned/contributed capital mix: A test of the life-cycle theory. J. Financial Econ. 2006, 81, 227-254. [CrossRef]

27. Hribar, P.; Yehuda, N. The mispricing of cash flows and accruals at different life-cycle stages. Contemp. Account. Res. 2015, 32, 1053-1072. [CrossRef]

28. Schein, E.H. What Is Culture; Sage Publications: Newbury Park, CA, USA, 1991; pp. 243-253.

29. O'Reilly, C.A.; Chatman, J.A. Culture as social control: Corporations, cults, and commitment. In Research in Organizational Behavior: An Annual Series of Analytical Essays and Critical Reviews; Staw, B.M., Cummings, L.L., Eds.; Elsevier Science: Washington, DC, USA, 1996; pp. 157-200.

30. Fekete, H.; Böcskei, E. Cultural waves in company performance. Res. J. Ecol. Bus. ICT 2011, 3, $38-42$.

31. Xenikou, A.; Simosi, M. Organizational culture and transformational leadership as predictors of business unit performance. J. Manag. Psychol. 2006, 21, 566-579. [CrossRef]

32. Sørensen, J.B. The strength of corporate culture and the reliability of firm performance. Adm. Sci. Q. 2002, 47, 70. [CrossRef]

33. Van Dyck, C.; Frese, M.; Baer, M.R.; Sonnentag, S. Organizational error management culture and its impact on performance: A two-study replication. J. Appl. Psychol. 2005, 90, 1228-1240. [CrossRef]

34. Dulaimi, M.; Hartmann, A. The role of organizational culture in motivating innovative behaviour in construction firms. Construct. Innov. 2006, 3, 159-172.

35. Boubakri, N.; Saffar, W. Culture and externally financed firm growth. J. Corp. Financ. 2016, 41, 502-520. [CrossRef]

36. Costa, B.A.; Crawford, A.; Jakob, K. Does culture influence IPO underpricing? J. Multinatl. Financial Manag. 2013, 23, 113-123. [CrossRef]

37. Savović, S. Organizational culture differences and post-acquisition performance: The mediating role of employee attitudes. Leadersh. Organ. Dev. J. 2017, 38, 719-741. [CrossRef]

38. Felipe, C.M.; Roldán, J.L.; Leal-Rodríguez, A.L. Impact of organizational culture values on organizational agility. Sustainability 2017, 9, 2354. [CrossRef]

39. Jiang, F.; Kim, K.A.; Ma, Y.; Nofsinger, J.R.; Shi, B. Corporate culture and investment-cash flow sensitivity. J. Bus. Ethic 2017, 154, 425-439. [CrossRef]

40. Galbreath, J. Drivers of corporate social responsibility: The role of formal strategic planning and firm culture. Br. J. Manag. 2009, 21, 511-525. [CrossRef]

41. Khedhaouria, A.; Nakara, W.A.; Gharbi, S.; Bahri, C. The relationship between organizational culture and small-firm performance: Entrepreneurial orientation as mediator. Eur. Manag. Rev. 2020, 17, 515-528. [CrossRef]

42. Lund, D.B. Organizational culture and job satisfaction. J. Bus. Ind. Mark. 2003, 18, 219-236. [CrossRef]

43. Gupta, Y.P.; Chin, D.C. Organizational life cycle: A review and proposed directions. Mid. Atl. J. Bus. 1994, 3, $269-294$.

44. Lim, D.G.; Jung, J.H. The impact of corporate product innovation on the firm's revenue and financial stability. J. Technol. Innov. 2017, 4, 239-261.

45. Kim, K.Y.; Atwater, L.; Patel, P.C.; Smither, J.W. Multisource feedback, human capital, and the financial performance of organizations. J. Appl. Psychol. 2016, 11, 1569-1584. [CrossRef]

46. Kang, M.-S.; Pan, H.; Ha, H.-Y. An empirical test of replacement costs of turnover using human capital corporate panel in Korea. Asia Pac. Bus. Rev. 2018, 24, 312-329. [CrossRef]

47. Wingard, D. Data-driven automated decision-making in assessing employee performance and productivity: Designing and implementing workforce metrics and analytics social sciences, sociology, management and complex organizations. Psychosociolog. Issues Hum. Resour. Manag. 2019, 7, 13. [CrossRef]

48. Chuang, K.S. Private placements, market discounts and firm performance: The perspective of corporate life cycle analysis. Rev. Quant. Financ. Account. 2020, 54, 541-564. [CrossRef]

49. Gill, A.; Biger, N.; Mathur, N. The effects of capital structure on profitability: Evidence from United States. Int. J. Manag. 2011, 4,3-15.

50. Cheng, M.C.; Tzeng, Z.C. The effect of leverage on firm value and how the firm financial quality influence on this effect. World J. Manag. 2011, 2, 30-53.

51. Vogt, S.C.; Vu, J.D. Free cash flow and long-run firm value: Evidence from the value line investment survey. J. Manag. Issues 2000, 2, 188-207.

52. Baek, J.-S.; Kang, J.-K.; Park, K.S. Corporate governance and firm value: Evidence from the Korean financial crisis. J. Financ. Econ. 2004, 2. [CrossRef]

53. Chay, J.-B.; Kim, H.; Suh, J. Firm age and valuation: Evidence from Korea. Asia Pacific J. Financ. Stud. 2015, 44, 721-761. [CrossRef] 